\title{
Positive Output Elementary Superlift Luo Converter for PV Applications
}

\author{
Dr.G.Justin Sunil Dhas ${ }^{1}$, Dr.D.Anto Sahaya Dhas ${ }^{2}$, and Sreesna $M K^{3}$
}

\begin{abstract}
In order to eliminate the effects of parasitic elements which will limits the output voltage and power transfer efficiency of DC-DC converters a new method is introduced i.e, voltage lift technique. VL technique is a popular and widely used method in electronic circuit design and it will improve circuit characteristics. Luo-converters are a series of new DC-DC step-up converters, which were developed from prototypes using voltage lift technique. The objective of this paper is to design and analyze a positive output elementary superlift Luo converter for photovoltaic applications. The solar panel model is developed using the basic circuit equations of photovoltaic cell. The unregulated voltage from the panel will be regulated by using the elementary super lift luo converter. It will reduce the voltage and current ripple. The positive output elementary Super lift Luo converter performs the voltage conversion from positive source voltage to positive load voltage and thereby giving the output voltage much higher than the original luo converter.
\end{abstract}

Keywords - pv cells, elementary luo converter, voltage lift technique

\section{INTRODUCTION}

$\mathrm{W}$ ITH the shortage of the energy and ever growing of the oil price, research on the renewable and green energy sources, especially the solar arrays and the fuel cells, becomes more and more important. To achieve high step-up and high efficiency, DC/DC converters are the major consideration in the renewable power applications due to the low voltage of PV arrays and fuel cells [1].The outputs of most of the renewable energy sources such as solar arrays and fuel cells are very low and dc-dc converters are employed to connect to the grid or battery pack. One of these converters is the positive output elementary Luo (POEL) converters which are based on the voltage-lift technique [3]. As compared with the other topologies used in $\mathrm{dc}-\mathrm{dc}$ conversion (step-up), Luo converters differ in the sense of constructional architecture which is of fourth-order-type architecture with a single active switch. The other characteristic feature of the Luo converter is its reduced ripple in both output voltage and current as compared with the conventional boost converter. The conventional types of DC/DC converters include Buck converter, Boost converter, Buck-Boost converter, Cuk converter etc. Among these, boost converter is found to be applicable in large number of applications like, Hybrid Electric Vehicles (HEV), lighting systems, tramways, railway electrification.

Dr.G.Justin Sunil Dhas ${ }^{1}$ is with Vimal Jyothi Engineering College, Kerala,India.

Dr.D.Anto Sahaya Dhas ${ }^{2}$ is with Vimal Jyothi Engineering College,Kerala,India.

Sreesna $\mathrm{M} \mathrm{K}^{3}$ is with Vimal Jyothi Engineering College,Kerala,India
The DC/DC conversion technique was established in 1920s. The simplest form of conversion was using voltage divider. Now various advanced methods are available for DC/DC conversion. It ranges from voltage lift technique to superlift and ultralift technique. Here, voltage lift technique is being used due to its simplicity, ease of use and economic nature. The voltage-lift technique can be successfully applied to several series of DC-DC Luo converters. Employing voltage lift technique has opened a way in designing high voltage gain converters. It allows voltage to be increased stage by stage. The positive output elementary super lift Luo converter is a new series of DC-DC converters possessing high-voltage transfer gain, high power density; high efficiency, reduced ripple voltage and current. These converters are widely used in computer peripheral equipment, industrial applications and switch mode power supply, especially for high voltage-voltage projects [1-6].

\section{PV CELL SYSTEM}

Photovoltaic offer consumers the ability to generate electricity in a clean, quiet and reliable way. Photovoltaic systems are comprised of photovoltaic cells, devices that convert light energy directly into electricity. Because the source of light is usually the sun, they are often called solar cells. The word photovoltaic comes from "photo," meaning light, and "voltaic," which refers to producing electricity. Therefore, the photovoltaic process is "producing electricity directly from sunlight." Photovoltaic are often referred to as PV. PV cells convert sunlight directly into electricity without creating any air or water pollution. PV cells are made of at least two layers of semi-conductor material. One layer has a positive charge, the other negative. When light enters the cell, some of the photons from the light are absorbed by the semiconductor atoms, freeing electrons from the cell's negative layer to flow through an external circuit and back into the positive layer. This flow of electrons produces electric current. The stand-alone photovoltaic energy system requires storage to meet the energy demand during period of low solar irradiation and night time. Battery storage in a solar system should be properly controlled to avoid catastrophic operating condition like overcharging or frequent deep discharging. Storage batteries account for the most PV system failures and contribute significantly to both initial and the eventual replacement cost. Charge controllers regulate the charge transfer and prevent the battery from being excessively charged and discharged. Switch mode DC to DC converters are used to match the output of a PV generator to a variable load. DC to DC converters allow the charge current to be reduced continuously in such a way that the resulting battery voltage is maintained at a specified value [4]. A practical photovoltaic energy conversion system. Block diagram is in Fig 1 


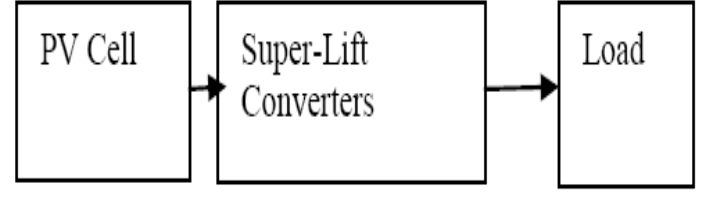

Fig. 1. Block diagram

\section{OPERATION OF ELEMENTARY SUPERLIFT LUO CONVERTER}

Super lift Luo converter significantly increases the voltage transfer gain stage by stage in geometric progression. The positive output elementary Super lift Luo converter (performs the voltage conversion from positive source voltage to positive load voltage and thereby giving increased output voltage.

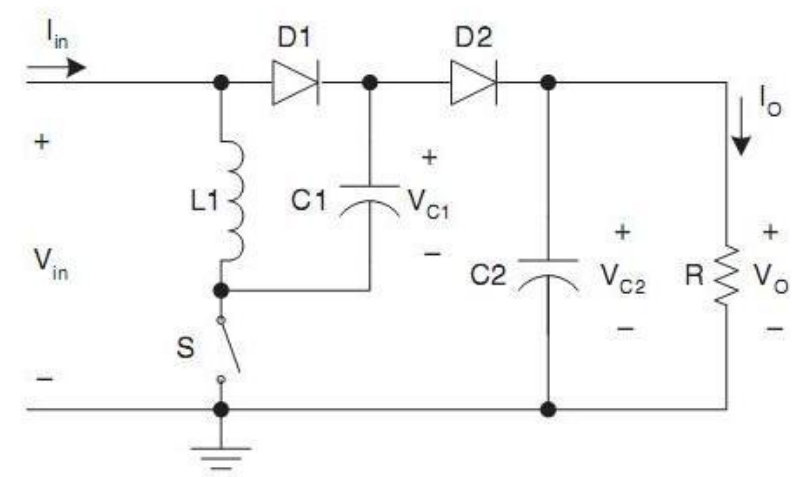

Fig. 2. Elementary circuit diagram

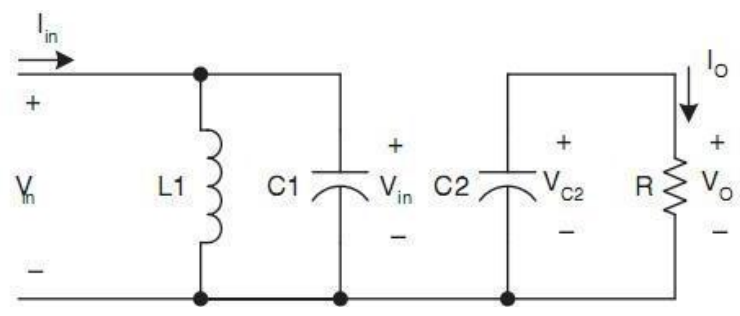

Fig. 3. Equivalent circuit during switching-on

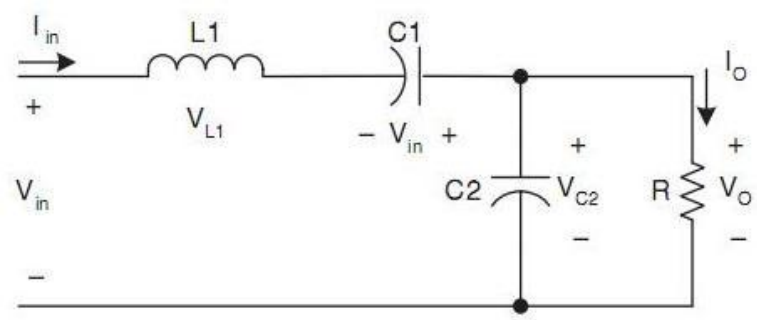

Fig. 4. Equivalent circuit during switching-off
The Elementary circuit and its equivalent circuit during switching-on and off are shown in fig 2, 3, 4. The voltage across capacitor $\mathrm{C} 1$ is charged to Vin. The current iL1 flowing through inductors L1 increase with voltage Vin during switching-on period DT and decreases with voltage (Vo-2Vin) during switching-off period (1-D) T. Therefore,

$\Delta \mathrm{i}_{\mathrm{L}}=\frac{V \mathrm{in}}{L} D T=\frac{\left(\mathrm{W}_{\mathrm{b}}-2 \mathrm{~W}_{\mathrm{L}}\right)}{\mathrm{L}}(1-\mathrm{D}) \mathrm{T}$

$\frac{\text { Vo }}{\text { Vin }}=\frac{2-D}{1-D}$

$\mathrm{T}=\frac{\mathrm{L} \Delta I}{\operatorname{Vin}}-\frac{\mathrm{L} \Delta I}{\left(\mathrm{~V}_{0}-2 \mathrm{~W}\right)}$

$\mathrm{L}=\frac{\operatorname{VinD}}{f \Delta I}$

$\Delta V c=\int_{D T}^{t} I o d t$

$C=\frac{\mathrm{V} 0(1-\mathrm{D})}{f R \Delta V c}$

IV. Simulation Of Elementary LuO CONVERTER

The simulation has been performed on the positive output Super lift Luo converter for pv system with parameters listed in Table1.

TABLE 1

PARAMETERS TO DESIGN ELEMENTARY LUO CONVERTER

\begin{tabular}{lll}
$\begin{array}{l}\text { Parameters } \\
\text { name }\end{array}$ & symbols & value \\
\hline $\begin{array}{l}\text { Input voltage to } \\
\text { converter }\end{array}$ & $\mathrm{VI}$ & 12 volts \\
\hline Output voltage & $\mathrm{Vo}$ & 36 volts \\
\hline Inductors & $\mathrm{L}_{1}$ & $16.66 \mathrm{H}$ \\
\hline Capacitors & $\mathrm{C}_{1}$ & $5 \mathrm{mf}$ \\
\hline Capacitor & $\mathrm{C} 0$ & $1 \mathrm{mf}$ \\
\hline $\begin{array}{l}\text { Switching } \\
\text { frequency }\end{array}$ & $\mathrm{fs}$ & $100 \mathrm{~Hz}$ \\
\hline Load resistance & $\mathrm{R}$ & $100 \Omega$ \\
\hline Duty ratio & $\mathrm{D}$ & 0.5 \\
\hline
\end{tabular}




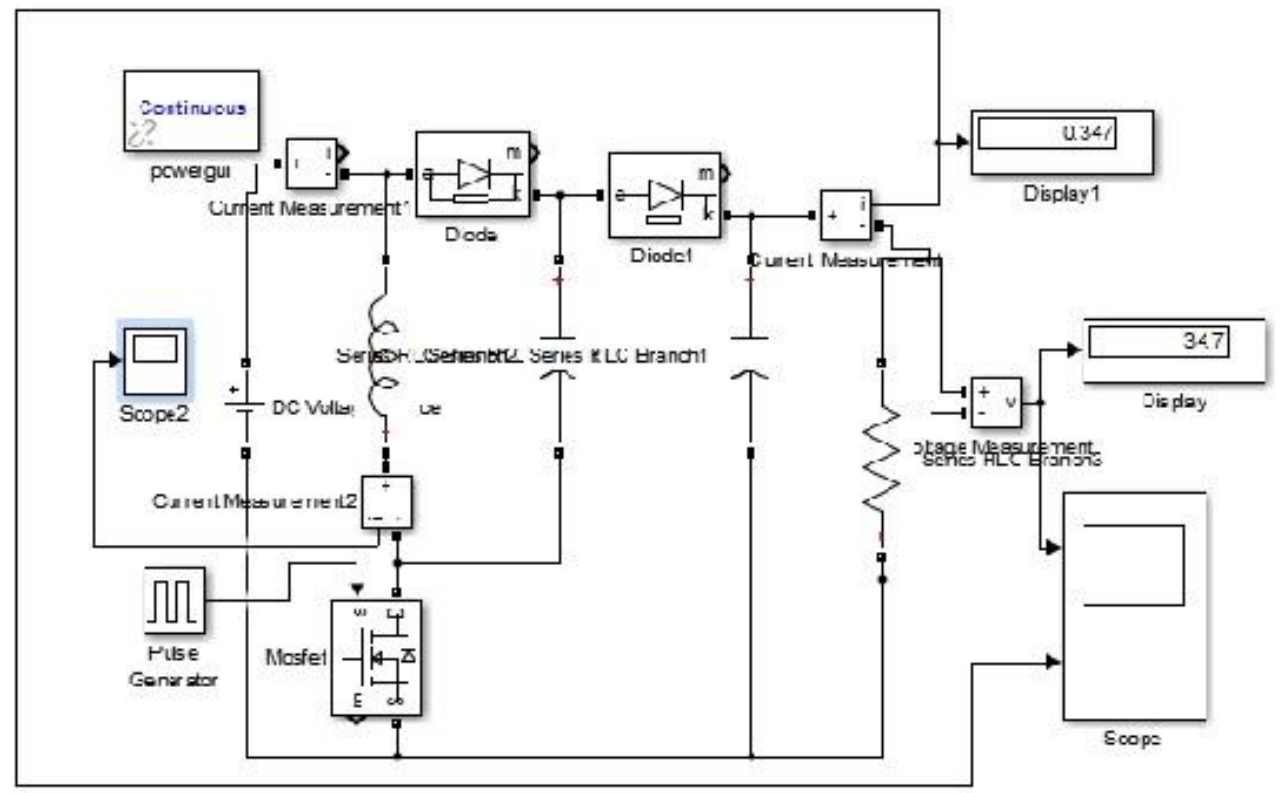

Fig. 5 Simulink Model for Super lift Luo converter

The positive output super lift luo converter is designed and simulated using MATLAB/Simulink and the output voltage from converter is shown in Fig. 5.

\section{Simulation OUtPut}

The positive output elementary luo converter is designed and simulated using MATLAB/Simulink ans the output voltage from converter is shown in Fig 6.

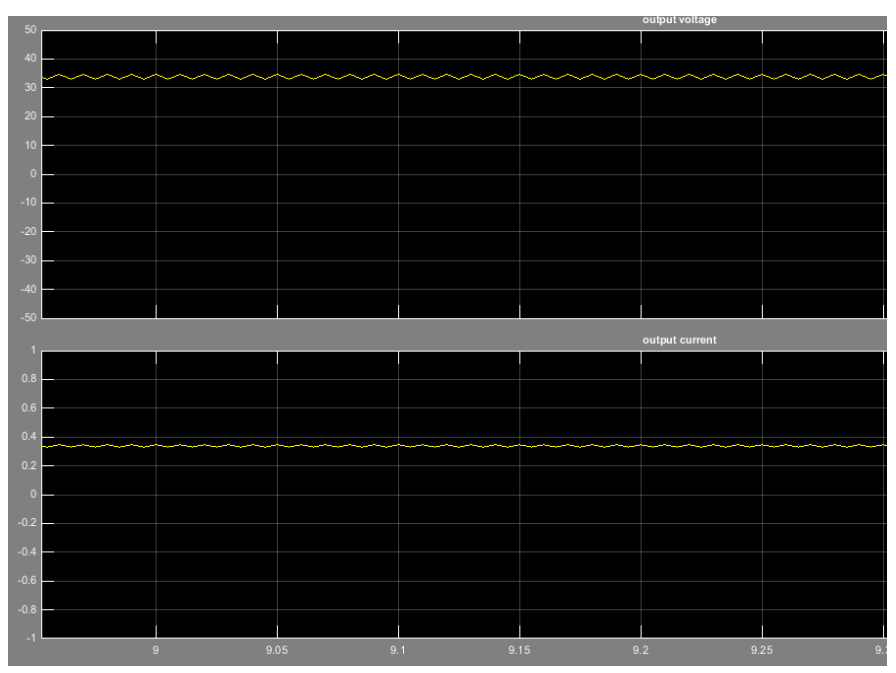

Fig. 6 Simulation results

\section{CONCULSION}

The positive output elementary super lift Luo converter (POESLLC) performs the voltage conversion from positive source voltage to positive load voltage. Due to the time variations and switching nature of the power converters, their dynamic behavior becomes highly nonlinear. The application of positive output elementary super lift luo converter in solar pv system produces voltages increasing in geometric progression. It produces output voltage of $36 \mathrm{~V}$ for the input voltage of $12 \mathrm{~V}$ from solar $\mathrm{pv}$ system. The converter have proved to be Robustness around the operating point, Good dynamic performance in the presence of input voltage variations and Invariant dynamic performance in presence of varying operating conditions.

\section{REFERENCES}

[1] He, Y.; Luo, F.L., "Positive output super-lift converters," IEEE Trans.Power Electron., vol.18, no.1, Jan 2003, pp.105-113. http://dx.doi.org/10.1109/TPEL.2002.807198

[2] Luo F. L. "Positive Output Luo-Converters, Voltage LiftTechnique"IEE Proceedings on Electric power Applications,Vol. 146, No. 4, July 1999, pp. 415-432. http://dx.doi.org/10.1049/ip-epa:19990291

[3] K.Prasanna, Dr.D.Kirubakaran, J.Rahulkumar, and J.A.Rudhran, "Implementation of Positive Output Super Lift Luo Converter for Photo Voltaic System,'” IRJET, Vol. 02, Issue: 03,June-2015.

[4] Sobuj Kumar Ray, Diponkar Paul, Tabassum E Nur, and Kamal Chandra Paul," A Preview on Simulation of Super-Lift Converter for Grid Connected Solar Installation" International Journal of Innovation, Management and Technology, Vol. 3, No. 2, April 2012.

[5] Luo, F.L, "Negative output Luo converters: Voltage lift technique", IEE Proc. B, Electr.Power Appl. Proceedings, 1999, 146, (2), pp. 208- 224 http://dx.doi.org/10.1049/ip-epa:19990302

[6] He, Y.; Luo, F.L., "Ultra-lift Luo-converter" in Proc. Int.Conf. Power Sys. Tech., 2004., pp.81-86 Vol.1, 21-24 Nov. 2004. 